\title{
High-resolution analyzed sedimentary records reveal the sedimentary changes in the continental slope of the Gulf of Alaska
}

\author{
MD NURUNNABI MONDAL ${ }^{1}$, KEIJI HORIKAWA ${ }^{1}$, \\ KATSUYA NEJIGAKI ${ }^{2}$ AND MASAFUMI MURAYAMA ${ }^{2}$ \\ ${ }^{1}$ University of Toyama \\ ${ }^{2}$ Kochi University \\ Presenting Author: mnmondal.fm@gmail.com
}

Understanding the paleoceanography of the down-core sedimentary profile of the northeastern Gulf of Alaska (GOA) required detailed investigation. Here, to construct the sedimentary condition, a sediments sample (KH17-3 CL14PC) was collected from the GOA $\left(59^{\circ} 33.35^{\prime} \mathrm{N}, 144^{\circ} 09.35^{\prime} \mathrm{W}\right.$, water depth $690 \mathrm{~m}$ ) continental margin in the northeastern North Pacific Ocean.

We generated high-resolution X-ray fluorescence core scanner records from the sediments sample covering the past 17200 years. These records together with a set of destructive geochemical data, and $\mathrm{Sr}-\mathrm{Nd}-\mathrm{Pb}$ stable isotopic records of bulk sediments, we constructed the detailed sedimentary status from Heinrich Stadial 1 (HS1) to the Holocene in the past climate intervals.

The analysis of our multiproxy records clearly showed that at $\sim 13-12.8$ cal. kyr BP and $\sim 3.1-2.7$ cal. kyr BP the GOA experience prominent sedimentary shifts.

According to the carbon/nitrogen $(\mathrm{C} / \mathrm{N})$ molar ratio the core bottom contains high terrigenous organic matter, and in the late $\mathrm{HS} 1$, the $\mathrm{C} / \mathrm{N}$ molar ratio further increased together with high carbonate content and abundance of ice-rafted debris. During the Bølling-Allerød, Preboreal, and in the late mid-Holocene $(\sim 2.7-$ 1.8 cal. kyr BP) the down-core sediment contains high marinebased organic matter. However, in the early Younger Dryas at $\sim 13.0-12.8$ cal. kyr BP, and in the late mid-Holocene at $\sim 3.1-2.7$ cal. kyr BP the GOA experience sedimentary shift due to the regional reglaciation. The high values of the $\mathrm{Ca} / \mathrm{Sr}$ ratio suggesting that high detrital carbonate content existed during these periods in the GOA continental margin sediments. This elevated detrital carbonate content comes from the basaltic detrital source suggested by the lower values of the proxy K/Ti ratio and that was responsible for the sedimentary shift in the region due to reglaciation. This interpretation of sedimentary shift occurred during the early Younger Dryas and the late midHolocene intervals further supported by the ${ }^{87} \mathrm{Sr} /{ }^{86} \mathrm{Sr}, \varepsilon \mathrm{Nd}$, and ${ }^{208} \mathrm{~Pb} /{ }^{204} \mathrm{~Pb}$ stable isotope records.

However, based on the new proxy records from the core KH17-3 CL14PC, we established a clear paleoceanographic framework for the regional sedimentary down-core profile in the continental margin of the high latitudes northeastern GOA. 